\title{
PHENOMENOLOGY, LAW, AND THE POLITICAL A METHODICAL REFLECTION ON FIRST-PERSON INQUIRY, NORMATIVE ORDERS, AND ACTION
}

\author{
Sophie Loidolt \\ (University of Kassel)
}

\begin{abstract}
In this paper, I investigate in which sense phenomenology as a first-person inquiry can or cannot address the phenomenon of law. Since law has been traditionally defined as a system of norms or a normative order, it is not immediately clear in which way a first-person approach regarding the experience and givenness of ... should yield elucidating insights about the phenomenon in question. The differences of the various phenomenological approaches to law partly root in how they deal with this issue. In my paper, (1) I present five different approaches how phenomenology can relate to law and legal theory in general. (2) Then I move to phenomenology as a first-person inquiry and problematize how such an inquiry, even if it deals with intersubjective and social phenomena, can or cannot approach the phenomenon of law. (3) Finally, I propose, as one of the ways of doing phenomenology of law, to combine it with the perspective of the political. For this I will look at Arendt's theory of action and how it relates to law. I work out how, from the perspective of a phenomenology of action and plurality, law appears in the multivalent character of petrifying action, of emerging from it and of enabling it. I propose a methodically reflected approach how the phenomenon of law could be tackled from this perspective.
\end{abstract}

Keywords: Phenomenology, law, theory of action, Arendt.

\section{Introduction}

There are many ways to do phenomenology of law. As the history of phenomenology of law shows, there are approaches that put the social act of promising and socio-ontological eidetics in the foreground; others that phenomenologically systematize Kelsen's Theory of Pure Law; then again others that choose an existential/ist 
angle or emphasize intersubjective and worldly features of law; and, finally, those that thematize law as an ex- and inclusive order-just to name a few.

In this paper, I want to investigate in which sense phenomenology as a first-person inquiry can or cannot address the phenomenon of law. Although I am aware that the ways to do phenomenology are certainly no less differentiated and divergent than the ways to do phenomenology of law, I regard the first-personal character of phenomenological inquiry to be one of its essential features. Phenomenology inquires into the structures of experience/consciousness/Dasein and its correlating world, with changing emphasis on either transcendental, existential, ontological, ethical, political, critical projects. Analyzing a phenomenon by speaking of its correlative givenness seems to be central for a phenomenological approach, and the intentional structure of givenness "of something for someone" by definition involves an angle of subjectivity. Hence, as soon as phenomenology speaks about experience and meaning, it does so by defending the intentional, subjective, first-personal, and correlational features of both, instead of conceptualizing them from the viewpoint of a third-person perspective.

Now, the methodical question with respect to developing a phenomenology of law is in which way the "phenomenon" law should be approached at all. Since law has been traditionally defined as a system of norms or a normative order, it is not immediately clear in which way a first-person approach regarding the experience and givenness of ... should yield elucidating insights about the phenomenon in question. The differences of the various phenomenological approaches to law partly root in how they deal with this issue. What I want to do in the following, is to present some reflections on this methodical problem, and then propose, as one of the ways of doing phenomenology of law, to combine it with the perspective of the political. For this I will look at Arendt's theory of action and how it relates to law. I regard this as an attractive option that can combine strong phenomenological insights with an interesting take on law, that, so far, has not been explored. ${ }^{1}$

\footnotetext{
${ }^{1}$ Although there have been recent publications that acknowledge Arendt's contribution to the philosophy of law, cf. Goldoni \& McCorkindale 2012.
} 
I will start out by (1) presenting five different approaches how phenomeno logy can relate to law and legal theory. (2) Then I move to phenomenology as a first-person inquiry and problematize how such an inquiry, even if it deals with intersubjective and social phenomena, can or cannot approach the phenomenon of law. (3) Finally, I turn to a phenomenology of action and plurality and propose a methodically reflected approach how the phenomenon of law could be tackled from this perspective.

\section{Phenomenological approaches to law: an attempt at systematization}

When trying to systematize the various different approaches in the phenomenology of law in a book a few years ago (Loidolt 2010) ${ }^{2}$, I mapped out four different ways in which phenomenology relates to law and legal science or legal theory in general. I will present these here and add another one which opens up a new interesting field of the constitution of intersubjective relations and the self through law. ${ }^{3}$

(1) Juridical/Assisting: A phenomenological approach that assists or complements legal science

Such a phenomenological approach would basically accept the categories and boundaries that are drawn by the respective legal theory it aims to complement. In the history of the phenomenology of law, the typical example would be the Vienna School of phenomenologists of law in the 1920ies, like Felix Kaufmann, Fritz Schreier, Alfred Schütz, and Tomoo Otaka who were all students of the famous jurist and legal philosopher Hans Kelsen - and of Husserl. All of these people were pursuing and phenomenologically

\footnotetext{
2 Some of the following passages I have taken from my book and translated into English. Einführung in die Rechtsphänomenologie presents an introduction to the phenomenology of law from its beginnings with Reinach up to contemporary authors working in the field.

${ }^{3}$ I have become acquainted with this new approach through the work of Emily Hartz (2014) and have had the chance to further develop some of these ideas with her. Some of the formulations I use here hence go back to our common work and inspiring discussions, for which I would like to express my gratitude.
} 
refining Kelsen's (2000) Pure Theory of Law by fruitfully combining it with Husserl's phenomenology.

Hence, a phenomenological analysis of this kind usually works in a given framework. It can either ask for its theoretical implications (Kaufmann 1922, Schreier 1924); or it can complement it with a social-ontological (Otaka 1932) or socialtranscendental (Schütz 1932/1960) theory, for example, a theory of acting subjects in a lifeworld. What does not happen in this approach, however, is the development of a phenomenological theory of law in its own right. The juridical approach mostly remains in the assisting and complementing role.

(2) Philosophical/Founding: A phenomenological approach that aims at the grounds of the phenomenon of law and a foundation of legal theory

This kind of approach represents the classical philosophical claim to explore the foundations of law in a philosophy of law. This could either be done, again, through social ontological theories (Reinach 1983, Stein 2006, Otaka 1932), or a theory of transcendental intersubjectivity (Schütz 1960, G. Husserl 1925), in which the constitution of law and legal orders would be located and would be conceived in a greater context: the context of constituting intersubjectivity, of society, of persons of higher order like the state and its representatives etc., or of the human being's existential constitution etc. What is mostly in the focus here is the dimension of the origin of law and legal orders as well as of the legal forms of living together. Reinach and his theory of promising as the origin of the meaning of "claim" and "obligation" would be a classic example. As another representative, Gerhart Husserl, Husserl's son, could be named: He claims that the apriori form of law's being is its legal validity and, eventually, its recognition in a legal community. These approaches mostly lead to a concept of law based on intersubjectivity, existentiality, social ontology, or social interaction. Another option is that they can lead to conceptualizing a law of reason (which, interestingly, only Edmund Husserl had in mind), or an ethical approach to law, which regards right mainly as "the right of the other" (Levinas 1987). 
(3) Political/Critical: A phenomenology that critically investigates the structure of law and legal theory

This phenomenological approach pays attention to analyses of power- and discourse-structures that constitute the legal field-and its theoretical comprehension. It therefore often points to "blind spots" in legal theory. A recent example for this is Hans Lindahl's book on the Fault Lines of Globalization (2013) in which he shows - by employing Bernhard Waldenfels' phenomenology of orders-how legal systems are always already constituted by boundaries, limits, and faultlines. The order and its outside that it relates to are reflected here. Such an approach either leads to an analysis of the legal order qua order, or to a critique of harmonizing theories of the origin of law (as we find it, for example, in Rousseau, Kant, or Rawls). By contrast, representatives of this approach rather point to ruptures, faultlines and breaks within the genesis of a legal order. Sovereignty, violence, power and their interrelations in the phenomenon of law are prominent themes here. What has also been thematized by Petra Gehring in terms of this approach, is a withdrawal in the givenness of law, amounting to a certain "nonphenomenality" of law due to its function as an invisible order (I will come back to this below).

What can be observed, however, is that these very interesting approaches often abandon the phenomenological method in favor of a more Foucaultian approach or a deconstructivist Derridean approach. This is not accidental and methodically relevant for our problem concerning a first-person approach to law. In general, it is noticeable that figures who are more on the margins of the phenomenological discourse provide the more helpful tools here (Arendt, Benjamin, Agamben etc.).

(4) Transcendental/Epistemological: A phenomenological approach which transcends legal theory and tries to elaborate an own understanding of the phenomenon of the juridical/the normative

This is an approach which aims at clarifying what it is that makes us fundamentally juridical or normative ("rechtlich") beings, both in theoretical as well as in practical matters. Questions like the following are asked: How come we are responsive 
to norms already in basic perception? What does it mean to be exposed to an appeal that confronts us with an "ought"? And how do the justificatory structures of critical reason emerge from these basic experiences? Why do we always already think in normative structures - and what does this amount to, in an epistemological, ethical, but also in a lifeworldly sense?

I have tried to elaborate on such an approach in my dissertation (Loidolt 2009), by going back to hints provided by Husserl, Scheler, Reinach, and Levinas, and also in recent papers, by investigating structures of experience and interaction, and by differentiating between operative, imperative, and critical normativity (Loidolt 2018). I believe that the topic of justification is so centrally embedded in human experience that it necessarily brings these fields together. It is important to emphasize, however, that these investigations transcend the phenomenon of law as well as legal theory, which is why I have put it at the end of my former systematization.

(5) Relational/Constitutional: A phenomenological approach that explores the ontologically constitutive function of law for subjectivity/intersubjectivity/society

The new approach I would like to add now (not claiming that this would be exhaustive) relates to more recent work in phenomenology on the constitution of the self in relation to others (cf. Zahavi 2014, Szanto/Moran 2016). This work, so far, has been focused more on developmental questions, on social cognition, on empathy, on socioontological structures etc. The question is if law also plays a role here. This would mean that it would have an ontological function for the constitution of the self in relation to others that could be demonstrated phenomenologically. I will come back to these questions in the third part of my talk. To be sure, this approach also shares elements with the "philosophical" (2) and the "political" (3) approach. It has, however, neither foundationalist ambitions, nor does it question the order in terms of order. Rather, it belongs to a theory of intersubjectivity that turns around the classical question of legal phenomenology: how law appears for a consciousness or how legal entities are generated 
by social acts. Instead, it asks the question how an individual comes to appear-or fails to appear-for itself and for others through law. ${ }^{4}$

\section{Phenomenology and law: How to capture the phenomenon?}

After these systematizing remarks, let me proceed to the question concerning the methodological difficulties of a first-person approach trying to capture a phenomenon like law. Let me start out by saying a few general things about phenomenology:

Phenomenology deals with the appearance of things which it takes to be the manifestation of the thing itself (and not a "mere appearance" in contrast to its real being). Equally important, phenomenology deals with the structure of appearance itself: This structure, called intentionality, is that appearance is always appearance of something for someone. Consequently, experience plays a principle role in phenomenology: It guides phenomenological investigation and its method-regardless of whether one locates experiences in a "sphere of consciousness" or one sees them as wordly enactments of givenness. All phenomenological propositions and methods must not only rise from the ground of experience, but they must also continuously prove themselves (ausweisen) in the final medium of experience. The famous slogans "To the things themselves!" (Husserl) and "No theories!" (Heidegger) have become paradigmatic for the resolve to refrain from construction in thought and only to rely on intuition with respect to what is given in experience. This opposition against constructive philosophy is paired with the

\footnotetext{
${ }^{4}$ This approach will remind some of the influential post-structuralist critiques of the last decades that have helped us to understand how law "produces" subjectivities and expresses power formations by going back to the theories of Foucault and Althusser (cf. Menke 2015, Butler 2006, Agamben 1998). Yet, what still misses, is a complementary phenomenological account that aims at a positive articulation of what "being through law" amounts to in experiential terms. Furthermore, a rather instrumental understanding of law continues to be predominant in theory and practice, which fails to recognize the subjective and intersubjective lived dimensions of law. With a phenomenological and existential approach, these dimensions of lived experience can be uncovered and examined: how law mediates - or fails to mediate-human action, and thus, individuality in plurality.
} 
establishment of a proprietary approach to experience. Experience is taken as a state of actualization in the first person and not as psycho-physical data which can be objectified by the scientific methods of experiment, measurement, and mathematization. Also, firstperson experience is not perceived in its empirical occurrence but in its general features: Phenomenology is thus not a psychological registration of experiential "matters of fact" but rather is in search of essential structures of experience.

Phenomenology is committed to the first-person perspective, but this first-person perspective is taken in its essential and universal features, and thus open to intersubjective criticism and verification. First-person experience is conceived as the primary, originary, and irreducible access to the world, not only of spatio-temporal things but also of thoughts or ideal entities. Perceiving, recollecting, fantasizing, conceptualizing, counting, remembering, loving, acting, singing, etc. are all different forms of consciously lived experiences, of "acts" or "comportments" (Verhaltungen) (Heidegger), each of which has their different correlates that can be analyzed phenomenologically.

When analyzing these experiences, phenomenologists first turn to their intentional structure: that in an act or in a comportment, something is "given," is present to someone. It would be a much too narrow view of intentionality if one conceived this only as an objectifying relation, or even as a functionalist one. Rather, as Heidegger (1988: 157f.) makes clear, "[i]ntentionality belongs to the existence of Dasein" and "[t]he co-disclosure of the self belongs to intentionality." Intentionality is thus the essential way in which Dasein/subjectivity exists and moves in the world, in contrast to a worldless stone. The intentional relation is not something Dasein occasionally entertains but which essentially characterizes its being: to be engaged in the world in everyday experiences, involving an implicit self-understanding. Hence, all of this happens not in a static frame stretched between a subject and an object belonging to different spheres, but as a dynamic movement in the world.

This is also how subjectivity is given to itself: it involves a co-constitution with the world and intersubjectivity. Phenomenology has a strong tradition of arguing that subjectivity and intersubjectivity belong together intrinsically. In contrast to Kant's view, where every subject possesses the same "transcendental apparatus," in phenomenology, 
the positions of subject and with-subject (Mitsubjekt) are not interchangeable without consequences. They form the initial transcendental situation and structure: the world is given to me and others, whose experience is not directly accessible like my own. Furthermore, the other is constitutive of my own concrete subjectivity, while, on the other hand, the access to him or her remains limited. And, finally, the constitutive role of intersubjectivity is not only decisive for the possibility of objectivity and the objective, real world, it also stretches into historic and generative dimensions. So we have (1) transcendental intersubjectivity, which constitutes the realness of the world, (2) generativity, pointing to investigations of tradition and history; and (3) social ontology, which addresses social acts, interaction and the building of communities (from the very starting point of empathy/Fremderfahrung as the kind of intentionality that gives me the other as an other animate being).

Now, after this very short characterization of phenomenology, we might ask ourselves: What kind of phenomenon is law? Is it experienced-and if yes, how, by whom? Does it appear? And, most importantly: What can we understand better about law if we look at it from the first-person perspective? What I want to focus on here is modern positive law, meaning the national, transnational, and international legal systems we all live in, and which Hans Kelsen and Niklas Luhmann have quite soberly described as "social technique" and "autopoietic system."

Although one could certainly say that law appears in the form of legal texts, legal practices, legal institutions, etc., Petra Gehring (2006) has her doubts that the access to the phenomenon of law, how it functions as an order, would be so easy. Law, that is, modern, positive law, is such a difficult topic for phenomenology, according to Gehring, because it does not have a form of appearance or evidence that could easily be captured by classical phenomenological concepts. It is not a content or correlate of an experience since it rather passively functions like an order-also of experience. Furthermore, it is also not a correlate of experience in the sense of the manifestation of an empirical object but rather a normatively ordering power. Therefore, Gehring assumes that the very givenness of law, the way how we experience it, is rather characterized by aspects of 
withdrawal. It inscribes itself so much into our practices on the one hand, and remains so abstract, technical and foreign to our everyday life on the other hand, that for the subject of the $21^{\text {st }}$ century one cannot claim a full experience of law anymore-like maybe the Hegelian citizen in his well-ordered state could have had. We are just as much children of Kafka as we are, ideally, self-transparent Hegelian citizens. This is why Gehring tends to see the juridical as a dispositive which is not only a functional or autopoietical whole, and which is not only linked to the political, but which is political in itself. It as a sui generis connection of power. What is developed here is a phenomenology of orders which takes decisive inspirations from Foucault and the poststructuralist insight that it is rather orders and discourses that constitute subjects' experiences than the other way around.

Much earlier, Alfred Schütz also seemed to have had doubts about the firstpersonal-accessibility of law and therefore clearly differentiated between "subjective sense" and "objective sense." This is especially interesting because we know that Schütz was a transcendental phenomenologist who did a lot of research on the intersubjective constitution of the social world. At the same time, however, he clearly seemed to recognize that law could not be captured in the form of a genesis of subjective and intersubjective sense-constitution only. Rather, he combined Kelsen's definition of law as a "social technique" and "normative scheme of interpretation" with Max Weber's notion of "ideal types." For Schütz, law resp. legal theory belongs to the "social sciences" which are "objective complexes of meaning of subjective complexes of meaning" (objektive Sinnzusammenhänge von subjektiven Sinnzusammenhängen) (Schütz 1960: 275). In the case of law this means that through an objective scheme of interpretation, "the norm," subjective situations are interpreted. This, as we know, is actually what the legal scientist and the jurist does all the time. What follows from this is that the social sciences certainly do not conceive the human being as a living Thou, but rather as a personal anonymous type, that is neither characterized by its conscious lived experiences nor by its spontaneity or duration (Schütz 1960: 275). Law is thus an ideal-typical construction which, in its interpretation of inter/subjective situations produces ideal types and an "objective," "third personal" legal complex of meaning that sometimes can differ 
quite significantly of how meaning in the situation is inter/subjectively constituted and experienced.

This gives us two reflected phenomenological stances, expressly dealing with the difficult relation between first-person experience and normative order: One addresses the constitutive power of orders and the withdrawal this amounts to in the realm of appearance and the experiential realm; the other points to the production of ideal types which then serve as a scheme of interpretation in the lifeworld. What I am interested in, is how the constitution and categorization/typing of experience through orders on the one hand and the analysis of lived experience of orders on the other hand, can go togetheron a methodical scale as well as regarding a deeper and multilayered perspective from which to tackle the phenomenon of law. To conceive it as a phenomenon of order which is at the same time an experienced order (experienced maybe also in its forms of withdrawal) can give us a phenomenologically refined and existentially rich understanding of law that combines first- and third-person perspective-and will need, furthermore, to include also the second-person perspective, in order to spell out its intersubjective reality. With Schütz' and Gehring's approaches in mind, I now want to propose how this could be done by turning to Arendt's phenomenology. I see her robust notions of action, plurality, and worldliness in relation to law as a possible link between Schütz' transcendental sociological and Gehring's Foucaultian approach. It can link these two reflected perspectives, because Arendt acknowledges the structuring, enabling, and idealizing functions of law without giving up on acting subjects and the intersubjective experience of acting and speaking as the core of being together. 


\section{Arendt's phenomenology of action and the role of law: A first draft}

The following notes are intended as a first exploration of the framework for such a broadly conceived phenomenology of law. Why do I think Arendt's conception is useful? ${ }^{5}$

(1) Arendt presents a theory of action which is not only political, but also intrinsically phenomenological and which manages to link the first-person singular with the first-person plural.

(2) She takes account of the fact that the nature of law is somehow foreign or alien to action viewed from the first-person plural, although, on the other hand, it emerges from the powers of action. What does this mean? For one thing, Arendt as a political theoretician, is of course interested in the founding of a republic, and in this sense also in the founding of a constitution and in the legislative process (in her book On Revolution she extensively analyzes the creation of the US-constitution by the so-called "Founding Fathers"). But of course, being a "Founding Father" is not our everyday life. In everyday life, we experience law rather as codifying and settling things in order to "tame" the boundless and anarchic space of action, to calm it down and to make it calculable by the means of contracts, sanctions, rules etc. for the sake of guaranteeing something secure in it.

(3) Yet, Arendt also acknowledges that the law creates a certain condition for a space of action to function at all. It gives stability, and a place in the world, it makes me count and makes my actions meaningful which would otherwise be evanescent and futile expressions of someone without a place and a status. Law, for her, is, in this sense, not so much viewed as the product of action but rather as the product of "work" (poiesis) in the

\footnotetext{
${ }^{5}$ I have elaborated a detailed account on the following issues in my "Habilitationsschrift" which will appear towards the end of 2017. In this book (Loidolt 2017), I develop a phenomenology of plurality by introducing Hannah Arendt's work into current debates taking place in the phenomenological tradition. I try to show in which way Arendt has to be understood in the context of the phenomenological tradition and thereby offer new perspectives on key concepts such as intersubjectivity, selfhood, personhood, sociality, community, and conceptions of the "we."
} 
sense of an architecture that frames a place and creates boundaries. ${ }^{6}$ It is precisely in totalitarian regimes, who seek to annihilate the public space and plurality, that the law loses this stability and gets accelerated in accord to the interest of the Volk or the proletariat (cf. Arendt 1973: 463f.).

These three aspects, I think, can help us to relate a first-personal inquiry that deals with the constitution of an intersubjective, social and political world, to the question of law. Arendt conceives the law and the legal system from the departing point of the space of action which is a space of appearance - and which is far more than a political lobby or strategy. Instead, and most importantly for Arendt's conception of the political, it is an existentially significant space for being and becoming a self among others. Of course, this is not the only way how to approach law. But I think it is a very genuine way how phenomenology can relate to law without giving up its first-person perspective and with keeping up a perspective that conceives the political from the viewpoint of acting, plural beings. To make this conceivable, I will now try to elaborate on each of these points and thereby also point to their interwovenness.

Ad (1) Let us first look at her concept of action, which is political: Arendt's conception of action has distinct features that discern it clearly from other standard takes on action: Action is praxis. It is neither to be confused with labor or work, nor is it to be mistaken for poiesis, techné or theoria. Action is "intersubjective and communicative" (Bernstein 1983:210) - like her notions of freedom, equality, speech, and power. Action as praxis-according to the Aristotelian notion-is something which finds its aim in its very performance (Vollzug). For Arendt, this means two things: First, performance

\footnotetext{
6 "An outstanding symptom of this prevailing influence is that the Greeks, in distinction from all later developments, did not count legisla ting a mong the political activities. In their opinion, the la wmaker was like the builder of the city wall, someone who had to do and finish his work before politicalactivity could begin. [...] To them, the laws, like the wall around the city, we re not results of action but products of making. Before men began to act, a definite space had to be secured and a structure built where all subsequentactions could ta ke place, the space being the public realm of the polis and its structure the law; legislator and architect belonged in the same category. But the se tangible entities themselves were not the content of politics (not Athens, but the Athenians, were the polis), and they did not command the same loyalty we know from the Roman type of patriotism." (Arendt 1998: 194)
} 
appears in the world; and second, this is relevant only to the extent that others are there. A lived experience of action is a lived experience of performance and appearance. These are just two aspects of the very same happening. Hence, because she takes appearance into account, Arendt makes others an integral part of action. Its medium and condition is plurality.

A definition of Arendt's conception of action must stress that it is a concept that is gained from the perspective of an "open we" on action. It focuses on action as it appears, not as it is intended (this can coincide, but does not have to coincide). To appear is to appear before others, in a world and in a context. It both enlightens and (mostly also) alters the context as well as it reveals the agent as partaker in the context (which means that the agent could not be revealed "outside" of the context). Action in this sense is praxis, the goal of which does not lie outside of performance/appearance but precisely "within" it: appearing and being revealed in the process of action are at least as important as the goals that I intend with it. It is thus the "how" of the performance that surpasses the "what" that the action intends. What I intend and who I am are elucidated by the "how" of my performance and have no appearance (or being) beyond it. Action in the Arendtian sense is thus intersubjective and bound to a holistic context. But it is also the irreducible event of a new beginning as opposed to a causal chain of reaction or the calculable pathways of behavior. The capacity to act is precisely to begin something new and to interrupt a chain of reaction. For Arendt, this is not a question of the will. Rather, it is an expression of the beginning that we ourselves are in being an irreducible perspective on the world, born into this world. Acting is existentially realizing this beinga-perspective and thereby translating what would otherwise not be accessible and realizable at all into plural existence. In this sense, the first-person perspective is exteriorized and linked to a first-person perspective plural: Arendt's subjectivity performs/enacts itself in the world and experiences worldly objects as well as subjects as worldly shining, as appearing for all.

Ad (2) Now, I think that it is important to note that this dimension of performance and of becoming a self among others has not very much to do with law for Arendtprecisely because here we are talking about natality/spontaneity, plurality, and 
uniqueness - something which stands in sharp contrast to the (ideal) types that law produces. In action and speech I get disclosed as a unique person and not as a subject of law.

Another fundamental description of action, its plural, first-personal keeping-upthe-flow, which Arendt directly links to creating a space of appearance and power is also something that stands in contrast to the fixed character of law. Political action, therefore, can very easily question the law and come in conflict with it. In this sense, political action, characterized as action in concert by many, can be the power which either legally or in a revolutionary way questions the law and demands a new order or, on a smaller scale, demands to change one specific law.

Arendt emphasizes again and again that the space that action creates enables the new to emerge, but at the same time is characterized by a certain boundlessness and instability. Backing away from these insecure features, philosophers and political theorists have repeatedly tried to establish other principles to guide human affairs: either that of philosophical and monologic "insight" into the just state, or that of supplying the category of work (or worse: of the "one interest" of the "invisible hand") for that of action. According to Arendt this dangerously makes the realm of human affairs into something which it is not, fostering 'the delusion that we can 'make' something in the realm of human affairs - 'make' institutions or laws, for instance, as we make tables and chairs, or make men 'better' or 'worse' - or it is conscious despair of all action, political and non-political, coupled with the Utopian hope that it may be possible to treat men as one treats other 'material.'” (Arendt 1998: 188)

Arendt famously names other remedies than these against this "despair," namely powers that belong to action itself: the acts of forgiving and promising. In the case of law, it is of course especially interesting to look at promising, all the more since one of the most famous phenomenological theories of law sees the origin of law in the social act of promising: Adolf Reinach's apriori doctrine of law. For Reinach, the social act of promising creates the legal entities (Rechtsgebilde) of claim and obligation, which are the ontological source for the normativity we associate with these terms. Putting it in a nutshell, Reinach's central argument is that promising belongs to a special group of acts 
which create social realities that are as real as houses or trees (cf. Reinach 1983:4), just that they ideal entities. By our contingent acts of promising we thus create binding obligations that exist independently of our subjective actualizations in an ideal sphere (I am still obliged, even if I have forgotten about it). It does not come as a surprise that Arendt does not engage in any "ideal sphere" talk. However, she agrees with Reinach that promises create bonds: "binding oneself through promises, serves to set up in the ocean of uncertainty, which the future is by definition, islands of security without which not even continuity, let alone durability of any kind, would be possible in the relationships between men." (Arendt 1998: 237)

The decisive difference with respect to Reinach, which again testifies for the categorial difference Arendt sees between law and action, is that the promise (like action) in certain sense has to remain in a state of actualization to be real: One cannot petrify promises in laws and store them there without anyone believing in them anymore. The probability that they will be broken, despite a sanction, is quite high. Hence, Arendt takes another angle than Reinach: Instead of investigating the origin of meaning of claim and obligation, she is interested in the concrete bonds that are created, and thus more interested in the intersubjectively binding than in the normatively binding. In this sense, she takes it to be an illusion that lived relations between people like promises could really be totally guaranteed by laws. It takes more than that.

What does this come down to? Action and law are in the relation of a firstpersonal-flow versus a "normative scheme" that is alien to it, while at the same time action founds the meaning of law. Law is thus constantly in the ambi- and multivalent position of petrifying action, of emerging from it and of enabling it. Let me further explain these important characteristics by turning to third point.

Ad (3) One of the most important functions of law, for Arendt, is its role in the creation of worldliness: Law stabilizes and structures the common world and the spaces of appearance in it: "It is as though the wall of the polis and the boundaries of the law were drawn around an already existing public space which, however, without such stabilizing protection could not endure, could not survive the moment of action and speech itself." (Arendt 1998: 198) But law not only stabilizes the space; it also gives 
people a place within it. As becomes most clear in Arendt's reflections on refugees and the aporia of human rights in Origins of Totalitarianism, the decisive function of law is this giving people a place, making them count, and thus preventing them from being "superfluous." Her famous demand for "the right to have rights" (Arendt 1973: 298) is nothing else than this demand to belong to a political community which is also always a legal community.

Arendt is thus not a theoretician who celebrates the political as existing only beyond or "outside" of the legal. (At the same time, of course, she tends to overlook the excluding inclusiveness of law.) She sees the political as something going on mainly inside the boundaries that were drawn by constitutional laws-without absolute guarantee, of course: "The limitations of the law are never entirely reliable safeguards against action from within the body politic, just as the boundaries of the territory are never entirely reliable safeguards against action from without." (Arendt 1998: 191) Yet, in everyday life, law does give us a stable place where we and our actions matter. We might not realize or experience it that much, but as soon as we fall out of it, it is clear that the enabling structure of law is vital for the worldliness of our actions. " What does "world" and "worldliness" mean? These are again notions that are very phenomenological loaded. For Arendt, the world is first of all a space of appearance which is constituted by the interrelations of human beings and the objects and projects they relate to (Dingwelt/Mitwelt). Arendt famously describes that living together in the world "means essentially that a world of things is between those who have it in common, as a table is located between those who sit around it; the world, like every in-between, relates and separates men at the same time" (Arendt 1998: 52). And with respect to mass society she adds: what makes it so "difficult to bear" is not primarily the number of people involved, "but the fact that the world between them has lost its power to gather them together, to relate and to separate them" (Arendt 1998: 52f.). The phenomenon of "world" she describes therefore possesses a certain "power" or is capable of losing that power. This

\footnotetext{
7 This is why a phenomenological analysis of "being through law" must start out with experiences of deprivation of a "placein the world."
} 
clearly indicates that Arendt never talks about mere things that simply lie around (being more or less enduring), even when she speaks about the world of things. Rather, she always talks about a web of relationships and the qualified space of visibility, contextualization, and reference that can present and hold together that which inter-est (which is in-between in the literal sense) (cf. Arendt 1998: 204). This is a space that can only be constituted by a plurality of subjects who form an in-between. According to Arendt, this "relating separation" is needed to develop our own identity in speech, action, and judgment.

Becoming a self with others means being in the process of struggle with others, by taking active positions, reflecting upon these positions, and acting according to them. The "worldliness" of humans is this interwoven and multilayered connection to others, to objects, to stories, within the whole of a context of involvements, as Dingwelt and, most of all, Mitwelt. Arendt names some conditions for the unfolding of our worldliness: "having a place in the world," which she calls "property" and "the most elementary condition for man's worldliness" (Arendt 1998: 253). In a related, transitive sense it can also be understood as citizenship and I would like to understand it in a broad sense also as an enablement through the legal system. Further conditions are a certain permanence and stability of the worldly space, a basic visibility in form of a public space and a functioning web of relationships.

If we want to speak about law how it is experienced from the first-personperspective, I think that worldliness and the ambivalent relation to action are two very important points to be considered. I would want to combine these points with what I have mentioned in the second part about the withdrawal of law and our experience of also being children of Kafka. Sometimes it seems as if positive law spans over an already existing intersubjective world of meaning (like in Schütz' account); there are spaces where we very meaningfully exist without the law as selves and others and interacting persons. Yet, one could question how much and where this really holds. If the structuring power of law remains invisible and unexperienceable, precisely because it allows for the experience of being a worldly subject, then the legal would have a much more ontologically relevant and productive function. Yet, this remains to be clarified. What Arendt has shown with 
her analysis of the situation of being a refugee and stateless person, is that any investigation on these matters must start by recognizing that the existential significance of realizing oneself through the medium of law is revealed most clearly in its absence: in zones of legal exclusion or transition where people's legal status is negotiated and changed. In this sense, I think both of these aspects: law as an ordering power-dispositive and law as an enabling place/status-provider, are crucial for understanding the phenomenon. And I think that they should be complemented by phenomenological analyses of experience in order to be able to give an existentially relevant account of how the law and legal order are given to us. 


\section{LITERATURE}

Agamben, Giorgio. 1998. Sovereign Power and Bare Life. Homo Sacer 1. Stanford: Stanford UP.

Arendt, Hannah. 1973. Origins of Totalitarianism. New edition with added prefaces. New York: Harcourt Brace Jovanovich.

Arendt, Hannah. 1998. The Human Condition. Chicago: University of Chicago Press.

Bernstein, Richard J. 1983. Beyond Objectivism and Relativism. Science, Hermeneutics, and Praxis. Philadelphia: University of Pennsylvania Press.

Butler, Judith. 2004. Precarious Life: The Powers of Mourning and Violence. London/New York: Verso.

Gehring, Petra. 2006. “Can the Legal Order 'Respond'?”, in: Ethical Perspectives 13/3, 469-496.

Goldoni, Marco, and Christopher McCorkindale. Eds. 2012. Hannah Arendt and the Law. Oxford, Portland: Hart.

Hamrick, William S. 1987. An Existential Phenomenology of Law: Maurice MerleauPonty. Dordrecht: Nijhoff.

Hartz, Emily, and Carsten Fogh Nielsen. 2014. "Freedom, Subjectivity and State in Hegel's Philosophy of Right," in: Post-Subjectivity. Ed. Christoph Schmidt, Merav Mack, and Andy R. German. Cambridge Scholars Publishing. 
Heidegger, Martin 1988. Basic Problems of Phenomenology. Revised Edition. Trans. Albert Hofstadter. Bloomington: Indiana UP.

Husserl, Gerhart 1925. Rechtskraft und Rechtsgeltung. Eine rechtsdogmatische Untersuchung. Band 1: Genesis und Grenzen der Rechtsgeltung. Berlin/Wien: Springer.

Husserl, Gerhart 1964. Recht und Welt. Frankfurt a. M.: Klostermann.

Kaufmann, Felix. 1922. Logik und Rechtswissenschaft. Grundriß eines Systems der Reinen Rechtslehre. Tübingen: Mohr.

Kelsen, Hans. 2000. Reine Rechtslehre. Nachdruck der Aufl. 1960. Wien: Österreich Verlag.

Levinas, Emmanue1. 1987. “Les droits de l'homme et les droits d'autrui, » in: Hors Sujet. Paris: Fata Morgana 1987.

Lindahl, Hans. 2013. Fault Lines of Globalization. Legal Order and the Politics of ALegality. Oxford: Oxford UP.

Loidolt, Sophie. 2009. Anspruch und Rechtfertigung. Eine Theorie des rechtlichen Denkens im Anschluss an die Phänomenologie Edmund Husserls. Dordrecht: Springer.

Loidolt, Sophie. 2010. Einführung in die Rechtsphänomenologie. Eine historischsystematische Darstellung. Tübingen: Mohr Siebeck.

Loidolt, Sophie. 2017. Phenomenology of Plurality. Hannah Arendt on Political Intersubjectivity. New York: Routledge. 
Loidolt, Sophie. 2018. "Experience and Normativity: The Phenomenological Approach," in: The Ideas of Experience. Phenomenological Explorations. Ed. A. Cimino, C. Coenen, and C. Leijenhorst.

Menke, Christoph. 2015. Kritik der Rechte. Berlin: Suhrkamp.

Otaka, Tomoo. 1932. Grundlegung der Lehre vom sozialen Verband. Wien/Berlin: Springer.

Reinach, Adolf. 1983. The Apriori Foundations of the Civil Law. Transl. J. F. Crosby. Aletheia 3, Philosophy of Law: 1-142.

Schreier, Fritz. 1924. Grundbegriffe und Grundformen des Rechts. Entwurf einer phänomenologisch begründeten formalen Rechts- und Staatslehre., Leipzig/Wien: Deuticke.

Schütz, Alfred. 1960. Der sinnhafte Aufbau der sozialen Welt. Eine Einleitung in die verstehende Soziologie (1932). Wien: Springer.

Stein, Edith. 2006. Eine Untersuchung über den Staat. Freiburg/Base1/W ien: Herder.

Szanto, Thomas and Moran, Dermot (eds.) 2016. The Phenomenology of Sociality: Discovering the 'We.' London/New York: Routledge

Zahavi, Dan. 2014. Self and Other: Exploring Subjectivity, Empathy, and Shame. Oxford: Oxford UP. 